\title{
Exploring Gamification Strategy for Developing MSMEs during the COVID-19 Pandemic
}

\author{
Arief Dwi Saputra a*, Alfina Rahmatia ${ }^{b}$, Sri Handari Wahyuningsih c, Andi Azhard \\ a Magister Management, Universitas Muhammadiyah Yogyakarta, Indonesia \\ ${ }^{b}$ Department of Sharia Banking, Universitas Ahmad Dahlan, Indonesia \\ c Doctoral Program in Management, Universitas Muhammadiyah Yogyakarta, Indonesia \\ ${ }^{d}$ Department of Business Administration, Asia University Taiwan, Taiwan \\ * Corresponding email: ariefdwisaputra18@gmail.com \\ http://dx.doi.org/10.22515/shirkah.v6i3.402
}

\section{ARTICLE INFO}

Keywords:

Entrepreneurial Behavior;

Entrepreneurship Education;

Gamification Strategy

\section{Article history:}

Received: 28 February 2021

Revised: 15 October 2021

Accepted: 03 November 2021

Available online: 31 December 2021

To cite in APA style:

Saputra, A. D., Rahmatia, A., Wahyuningsihm S. H., \& Azhar, A. (2021). Exploring Gamification Strategy for Developing MSMEs during the COVID-19 Pandemic. Shirkah: Journal of Economics and Business, 6(3), 380-398.

\section{ABSTRACT}

The COVID-19 pandemic brought about employees to be less enthusiastic due to the declining competitiveness and switching systems from offline to online. This study closely scrutinized how gamification strategies assume a part in entrepreneurial behavior on attitudes, subjective norms and behavioral control, and entrepreneurial education through self-efficacy, experience, and program involvement. Purposive sampling was utilized to choose a sample of 442 informants for this qualitative study. The review was carried out through a literature study and reinforced by in-depth interviews. The data was coded using the Nvivo 12 application with word similarity analysis at a maximum percentage of $100 \%$. Based on the results of word similarity, there was a similarity in the relationship related to cluster analysis which classified the mutually supportive roles among variables as a business strategy during the pandemic. Overall, the application of gamification displays an impact on motivation, behavior change, and psychological effects on entrepreneurial behavior and education. The research contribution is utilized to address issues in the role of the organization as a solution to the relationship between gamification strategies and employee performance. The application of gamification strategies plays a role in opening fascinating exploration in the future. Further studies are expected to discuss pertaining business strategies in dealing with unexpected moments such as the COVID-19 pandemic. 


\section{Introduction}

The emergence of the coronavirus (COVID-19) pandemic that happened all of a sudden at the beginning of the year 2020 had a massive impact on people's lives, including the economy. In light of the data in the first quarter of 2020, there was a $2.97 \%$ decline in economic movement (year-on-year) compared to the first quarter of 2019 that reached $5.07 \%$ (Badan Pusat Statistik, 2020). This is closely related to the MSME movement, which is becoming increasingly prevalent in the new normal era because it is progressively being echoed within changes in the economic order (Fahriyah \& Yoseph, 2020).

The pandemic resulted in employees becoming less enthusiastic about declining competitiveness as well as system changes from offline to online resulting from an updated managerial process system (Fahriyah \& Yoseph, 2020). It is, nevertheless, not different from the organizational aspect, which serves as the engine for increasing employee knowledge and abilities (Hendrawan et al., 2018). Therefore, a strategy is required to foster motivation, enhance entrepreneurial behavior, and strengthen entrepreneurial education. An appropriate strategy will affect the stability of the business to confront the new normal era.

This study analyzed the relationship between entrepreneurial behavior and gamification despite the two related schemes in the entrepreneurship literature is still not well established empirically. Many of these areas are dealt with separately, especially from an organizational perspective (Huotari \& Hamari, 2017; Vesa et al., 2017), yet it can be used as a benchmark (Liñán et al., 2011; Mwasalwiba, 2010). Researchers bridge these three areas by investigating how gamification can be a business recovery and enhancement strategy in influencing entrepreneurial behavior from the organization's entrepreneurship education programs.

In a business context, the relevance of gamification is considered not only from a business perspective but also from an educational point of view (Kuratko \& Morris, 2018). Investigation of gamification has been carried out mainly to motivate users to participate in more enjoyable programs (Deterding, 2011; Korn \& Schmidt, 2015). Submission of schemes through the concept of motivation (Seaborn \& Fels, 2015) and satisfaction demands theory (Ryan \& Deci, 2020; Ryan et al., 2014). Gamification is associated with significant findings in similar research concerning engagement, satisfaction, and motivation (Deterding et al., 2011; Huotari \& Hamari, 2012; Hamari et al., 2014).

Another study shows that gamification improves entrepreneurial behavior by utilizing human resources and social skills, both of which are necessary for entrepreneurship (Antonaci et al., 2015). In general, empirical studies found that entrepreneurial behavior is influenced by gamification with user experience and 
engagement, and motivation abilities (Deterding, 2011; Dichev \& Dicheva., 2017; Fathian et al., 2021; Gimenez-Fernandez et al., 2021; Houtari \& Hamari, 2017; Kalafato, 2020; Saputra \& Rahmatia, 2021; Wünderlich et al., 2020).

As a result, gamification transforms into the primary trend, not merely a passing fad that must be incorporated in future business strategies when internal and external influences are confronted with sources of income through the business, regardless of the model (Storbacka et al., 2016). Organizations foster gamification activities promoted to business through programs to facilitate consumers, employees, and students viably for assisting in developing skills such as teamwork, organizational procedures, and organizational best practices (Kristensson et al., 2017; Poole et al., 2014).

Rauch \& Hulsink (2015) have proven that educators can develop options for teaching models consisting of games and simulations. However, restricted proof and examination on studies pertaining to performance, motivation, involvement, and behavioral development results in the scarcity of the application of gamification (Dichev \& Dicheva, 2017; Kristensson et al., 2017). Development in the future in the form of more research into the effects of gamification will be crucial for the organization's reach (Larivière et al., 2017; Mačiuliene \& Skaržauskiene, 2016).

This review endeavors to contribute to organizations that offer linkage solutions regarding the applying a Gamification Strategy to stimulate entrepreneurial behavior and entrepreneurship education as a business recovery strategy. In this manner, this study examined the possible effects of adopting an approach to processes and programs that add to organizational capabilities and knowledge. To that end, this research presents an outline of the application of the Gamification Strategy. The outcome of the analysis endows the mechanisms that can be used. This research seeks to bestow to organizations that offer linkage solutions related to gamification strategies to stimulate entrepreneurial behavior and entrepreneurial education as business recovery strategies. Thus, this study deciphers the possible effects of approaches for processes and programs devoting to organizational capabilities and knowledge.

To achieve this, this study provides an overview of the implementation of gamification strategies. The mechanism starts from identifying obstacles (intrinsic or extrinsic) that can generate interest in work by providing relevant gamification models (point, reward, challenge, and leaderboard). The next step is creating a practical and enjoyable work experience using scenarios, simulations, and challenges. The next step is providing feedback (rewards, thanks, and suggestions) to improve performance, which might assist employees in thinking creatively and innovatively to maintain employee motivation and moments. Then, repetition was applied to achieve successful behavior change. The results of the analysis decipher the mechanism that can be used. Furthermore, the results are presented and discussed along with limitations and 
suggestions. This study also offers recommendations for business actors in encountering the new normal era.

\section{Gamification in Business and Entrepreneurship}

The use of game models in non-game contexts has been defined as gamification (Deterding, 2011). Robson et al. (2016) defined it as changes in non-game behavior conditions in the application of game model principles. It is in line with Deterding (2011), but instead of motivating, this research refers to behavior change. Robson et al. (2016) analyze how the companies are playing by creating a more engaging experience through a traditional approach by facilitating behavior change through customer engagement and employee. These researchers assume that change is channeled through intrinsic rewards and extrinsic assistance.

Barata et al. (2017) assert that gamification entails the user in adopting a variety of behaviors that are typically associated with commercial definitions. This definition suggests a general process in which gamification includes three types of elements such as emotions, mechanisms, and dynamics (Sailer \& Homner, 2020). Referring to Hamari et al. (2014), Gamification can be inferred on three dimensions including psychological abilities, motivation, and behavior. Dicheva and Dichev (2017) take it a step further that gamification is not only a tool for changing behavior, but also has something to do with technology.

Although the compulsory gamification segment has not been analyzed, there are some that are most widely used or referenced, such as experience points and levels (used for ranking, feedback, and progress goals), challenges or quests (tasks with clear objectives and increasing difficulty level), Badges or rewards (which are distributed to increase motivation) and leaderboards (which stimulate competitiveness and continuous improvement) (Barata et al., 2017).

Likewise, Kevin Werbach (2012) points out the trinity of gamification design of awards (levels) or badges, points, and leaderboards. This concept can be implemented in both empirical and theoretical domains with applications in areas such as education, marketing, health care, human resources, training, environmental protection, and organizational well-being (Seaborn \& Fels, 2015). For the most part, the potential is commonly regarded to promote engagement, motivation, friendly competition, collaboration, behavior change in different contexts including employee performance and social loyalty (Dicheva \& Dichev, 2017). Nonetheless, multidisciplinary literature analysis of the numerous findings on gamification-based program development is required to examine the specification (Deterding, 2011).

Even though the goal-setting theory has been used to study gamification, psychological theories are most frequently employed in gamification research because 
they focus on psychological growth that covers the need to feel competent, they need to feel connected to others, and the need for autonomy (Seaborn \& Fels, 2015), and the situation needed to improve the action of developing those needs (Ryan et al., 2014).

Research shows that gamification can escalate activity (Denny, 2013) and performance (Domínguez et al., 2013), However, empirical studies that mainly refer to entrepreneurship have yet to be established. In addition, Nacke \& Deterding (2017) assume that there is a lack of other research that assesses behavioral outcomes outside of what is generally assessed. To our knowledge, there are only a handful of studies exploring the effect of gamification on entrepreneurial behavior through entrepreneurship education. To that end, this review pores over the relevant options.

\section{Method}

To address the research gaps and investigate this research, a qualitative strategy using literature studies (from reputable journals) and interviews was employed. The selection of a qualitative approach is based on a method for finding and collecting data that is intuitive and sensitive enough to see every symptom that exists in the study object in social contexts. In addition, it can be useful for practical applications by providing an opportunity to develop specific insights on studies investigating gamification. The research process is indispensable in determining the research flow chart and the initial research concept. In this study, the research flow chart is depicted in Figure 1.

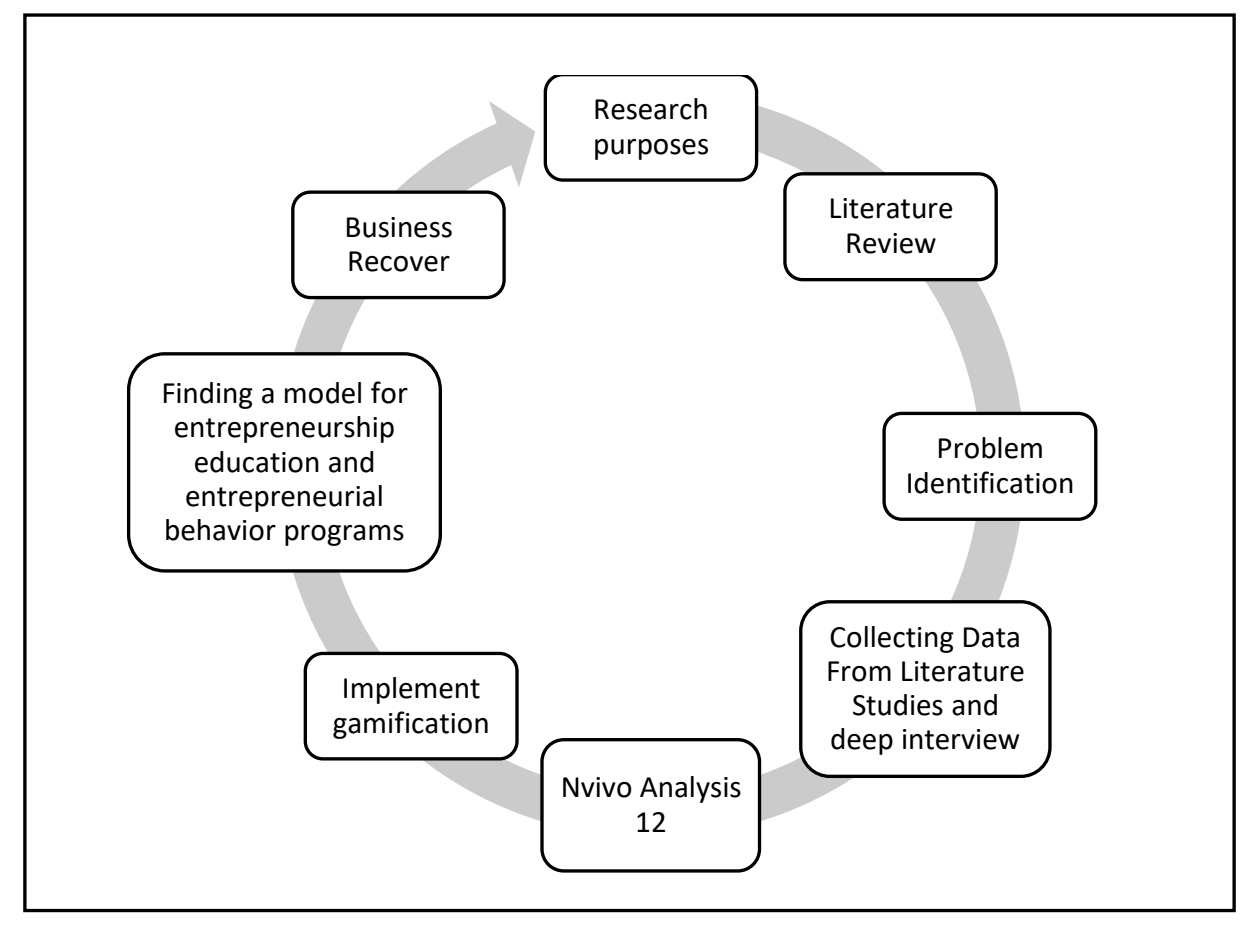

Figure 1. The Research Process 


\section{Research Design}

Figure 1 delineates the early stages of research that started with constructing the objectives for the research as a basis for compiling research at the next stage. In addition, empirical studies were also conducted by collecting data from in-depth interviews to see the extent to which the research relates to the reviews. The required data was collected and analyzed through the Nvivo 12 application in the next stage. Furthermore, a proposed dimension is assembled from theoretical and empirical studies to establish a program model in entrepreneurship education and entrepreneurial behavior using gamification in the hopes of forming entrepreneurial intentions as business recovery strategies in the future.

\section{Participants Selection and Data Sources}

In this study, interviews were administered using the Zoom application to 13 informants for each managerial unit. There are a total of 442 informants in this study. In collecting information as a data source, the technique that was employed to improve the outcomes of interview coding is by using sentiment analysis which is done manually using the emoticon feature or answering the questions directly with the Raise Hand feature. The interview's interpretation is developed by asking questions and replying to them by using a Raise Hand feature (agree or disagree) to strengthen or weaken. The interview process was completed by selecting resource persons with expertise and qualifications equivalent to those of the researcher, on the condition that the informant was the person who knew the most about himself, was true and trustworthy, and equated the informant's and researcher's interpretations of the research topic.

The sample of this research is the management of MSME run by students, namely the Presidium.ID, a business charity in the Muhammadiyah Student Association. Consisting of 34 Provincial Leaders throughout Indonesia, they comprise the Branch Leaders, Branch Managers, and Regional Leaders in a hierarchical structure. The sampling technique used was based on judgment or purposive sampling. The sample was selected adhering to specific criteria set by researchers (Nurdiani, 2014), namely 13 Marketing Executive (ME) in elected management representing each leader of each province. The data was collected through interviews via the Zoom and Google Meet applications. The overall sample consisted of 34 regional leaders in provinces with 13 students in each regional leader representing 442 respondents.

\section{Data Collection}

Collecting data through literature studies (from reputable journals) and interviews was carried out for data collection. First, the authors determined criteria for reviewing the literature and locating elements connected to gamification. Journals were chosen for 
their relevance to the area and because they were accredited, respectable, and indexed by reputable indexers. Journal articles were compiled through Google Scholar within the last 10 years. Further, interviews were conducted to strengthen the study so that results on the application of the Gamification Strategy could be obtained afterward.

The interview process was carried out by identifying the intrinsic or extrinsic elements that occur. The steps include the preparation in determining the interview topic, collecting information as a data source, determining the appropriate sources and following the interview topic, and compiling a list of questions or an outline of interview questions. The data collection prioritized basic ethics in interviews such as greetings and introducing the objectives of this study. The questions were delivered in polite language. Noting and recording were carried out to provide evidence of the results of the interview. After the interview, appropriate etiquette was performed to ask for the availability of sources to be contacted again if there is anything that needs to be confirmed or completed. Then, the compilation of the results of the interview was done by re-checking the results of the interview by rewriting it as needed without changing the content of the interview.

The list of questions is compiled by reviewing how far gamification strategies such as points, rewards, challenges, and leader boards can be applied and can provide support in doing business during the pandemic. The questions were reviewed to realizing the Gamification Strategy in providing support for behavior change, motivation, and psychological effects on MSME business actors. Question items were scrolled one by one such as what, why, and how the elements of points, rewards, challenges, and leader boards can improve entrepreneurship behavior and entrepreneurship education. Then, the interview was developed by check up on the application of points, rewards, challenges, and leader boards on the compiling indicators as an agenda to strengthen each review through attitude, subjective norm, and behavior control in entrepreneurship behavior and self-efficacy, experience, and involvement in entrepreneurship education.

\section{Data Analysis}

The data was analyzed using Nvivo plus 12 through coding similarity analysis for conclusion drawing. Nvivo was used to analyze qualitative data for more professional results (Hilal \& Alabri, 2013). To strengthen this research, in addition to a literature review with reputable journals, data collection was also carried out using sampling techniques with word similarity analysis at a maximum percentage of $100 \%$. To determine the sample whose number corresponds to the sample size, the researchers paid attention to the population's characteristics and distribution for a representative sample (Sholikhah, 2016). 


\section{Results}

This study illustrates the results from Figure 2 to Figure 7 with a total percentage of $100 \%$ on the Gamification Strategy applied to entrepreneurial behavior and entrepreneurship education on six elements, each involved sequentially.

Figure 2 to Figure 4 show that the Gamification Strategy in entrepreneurial behavior is implemented to see how gamification strategies play a role in motivating, changing behavior, and providing psychological effects on employees in terms of attitudes, subjective norms, and behavioral control to deal with unexpected moments such as the current pandemic.

Entrepreneurial behavior plays a significant role in employee performance and will affect the business. This study shows that the application of the Gamification Strategy provides a more dominant role in behavioral control as observed from changes in behavior and psychological effects. Meanwhile, in motivation, attitude is more dominant than the other two elements. Subjective norms do not exhibit a dominant effect on any impact on the Gamification Strategy.

This is illustrated by the behavior control that reaches a maximum percentage of $46 \%$ (Figure 3) impacting behavior change. Furthermore, the maximum total percentage in the attitude element exceeds that of the other elements by $50 \%$, which has an impact on motivation. Meanwhile, subjective norms received the lowest percentage of all effects of application and the lowest was the psychological effect of $14 \%$.

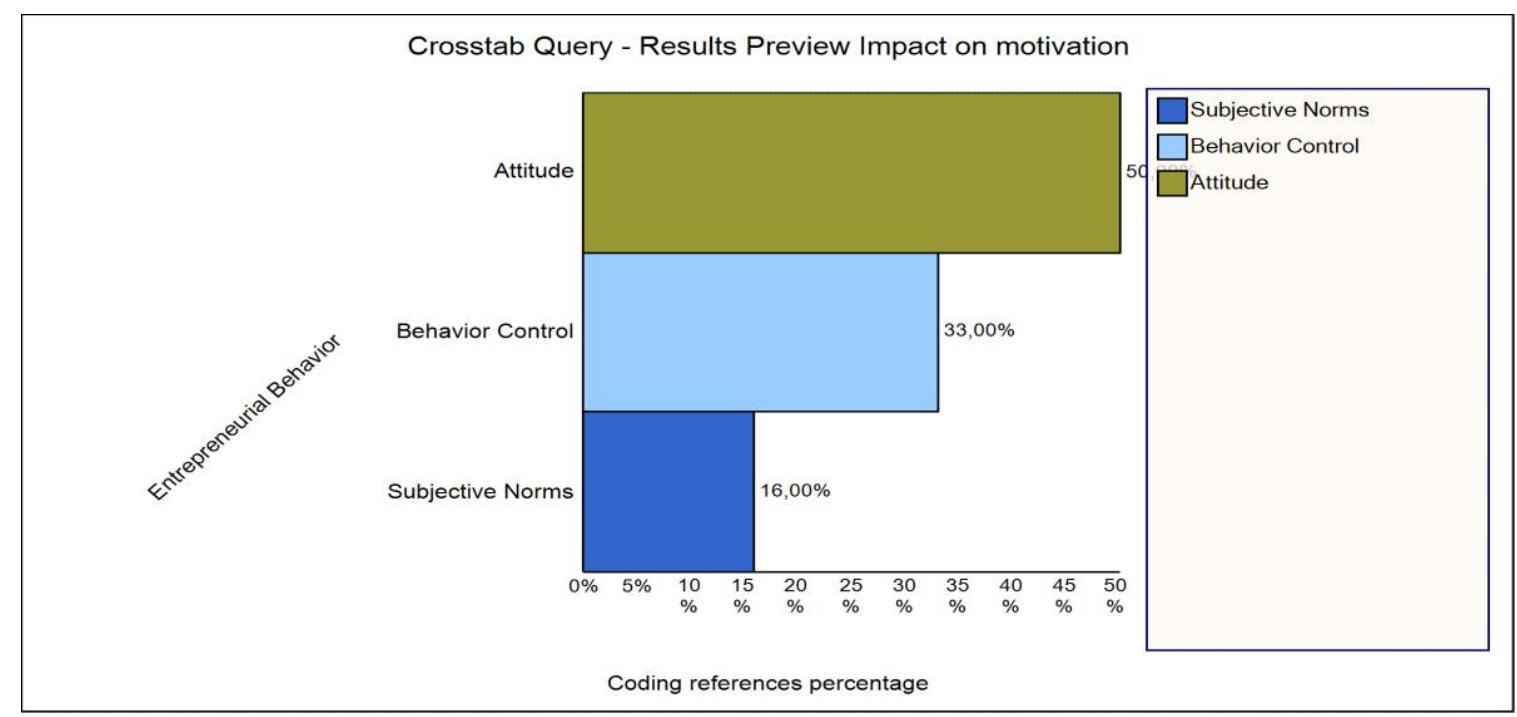

Figure 2. Application of a Gamification Strategy (Impact on Motivation based on Entrepreneurial Behavior) 


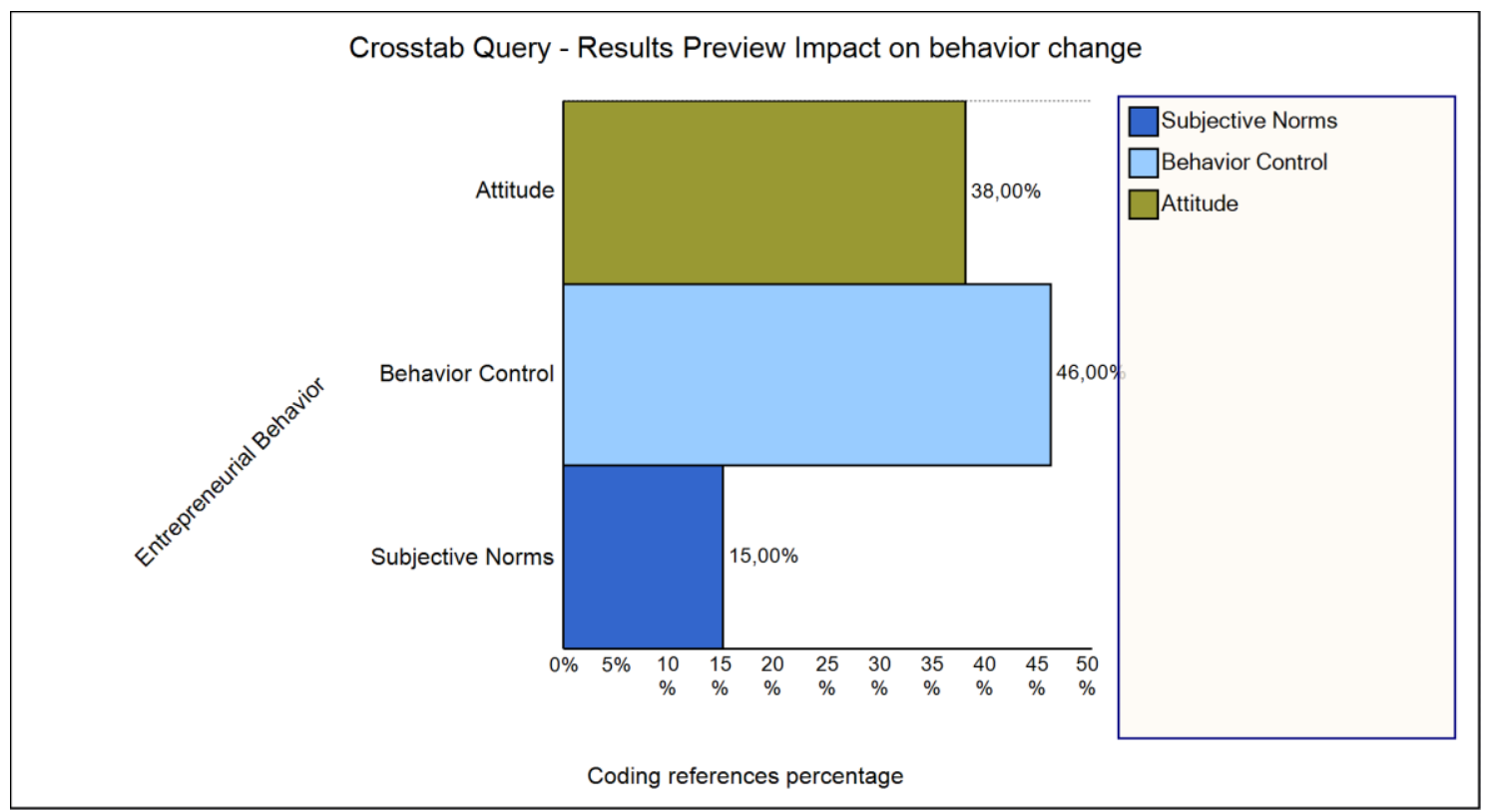

Figure 3. Application of a Gamification Strategy (Impact on Behavior Change based on Entrepreneurial Behavior)

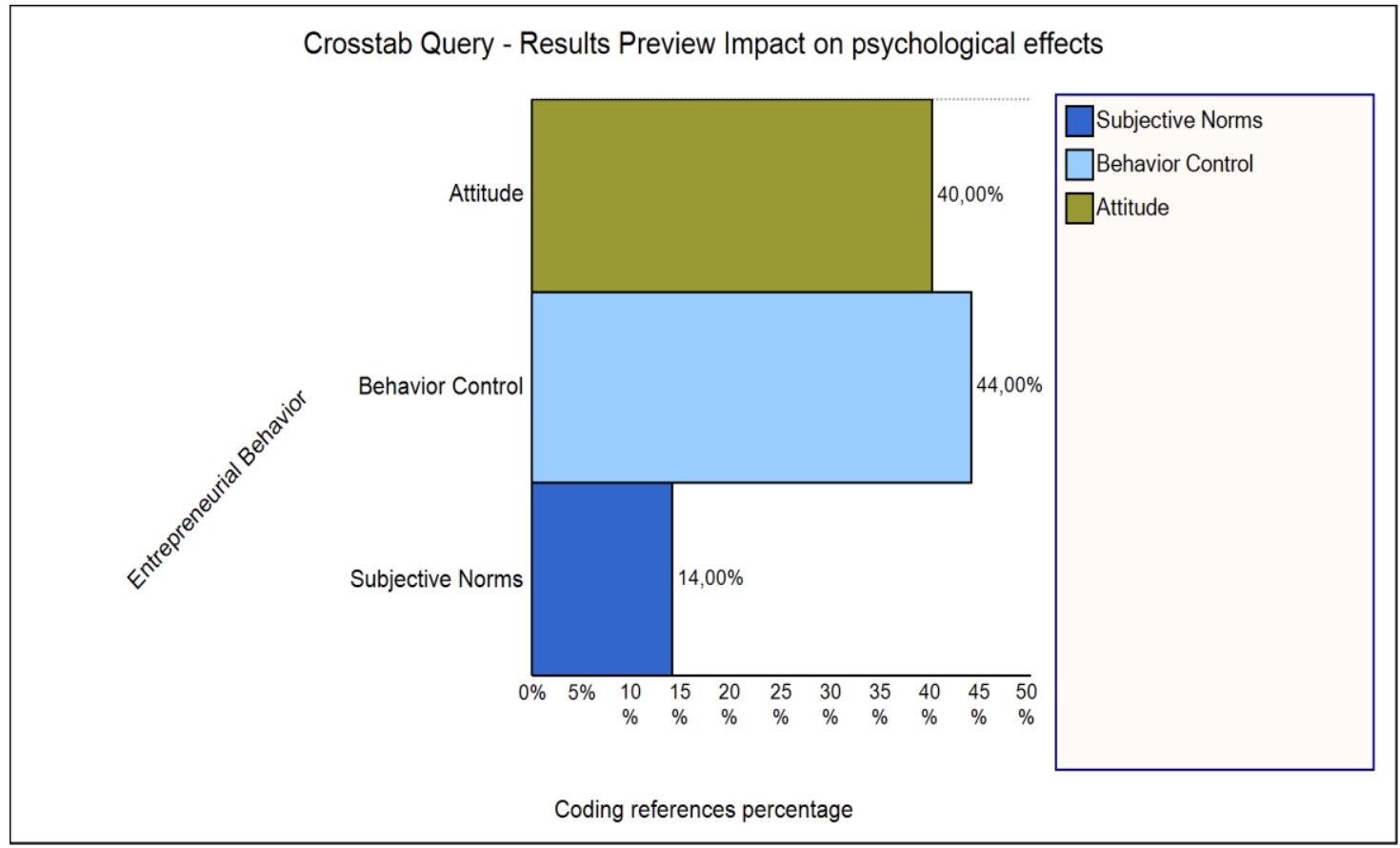

Figure 4. Application of a Gamification Strategy (Impact on Psychological Effects based on Entrepreneurial Behavior)

Furthermore, Figure 5 to Figure 7 suggest the exact role of gamification strategies applied to unstable business processes and are encountering several system changes. Finally, entrepreneurship education is reviewed through elements of self-efficacy, experience, and employee involvement. It will have an impact on motivation, behavior change, and psychological effects.

The Gamification Strategy explains the experience element as a more dominant 
element among other elements by contributing to changes in behavior and psychological effects. For example, in motivation, the element of self-efficacy becomes more dominant and is the most extensive one with a total percentage of $54 \%$ in its application. Then, the involvement becomes the lowest constant element at each impact by the Gamification Strategy except for behavior change.

It is the greatest percentage figure that plays a role in the experience, at 39 percent. Although self-efficacy received the greatest overall percentage rate, it had no more impact on behavior change than the element of involvement, which received $26 \%$. Nevertheless, involvement is the lowest element among other elements, with the lowest percentage of $18 \%$ in motivating employees.

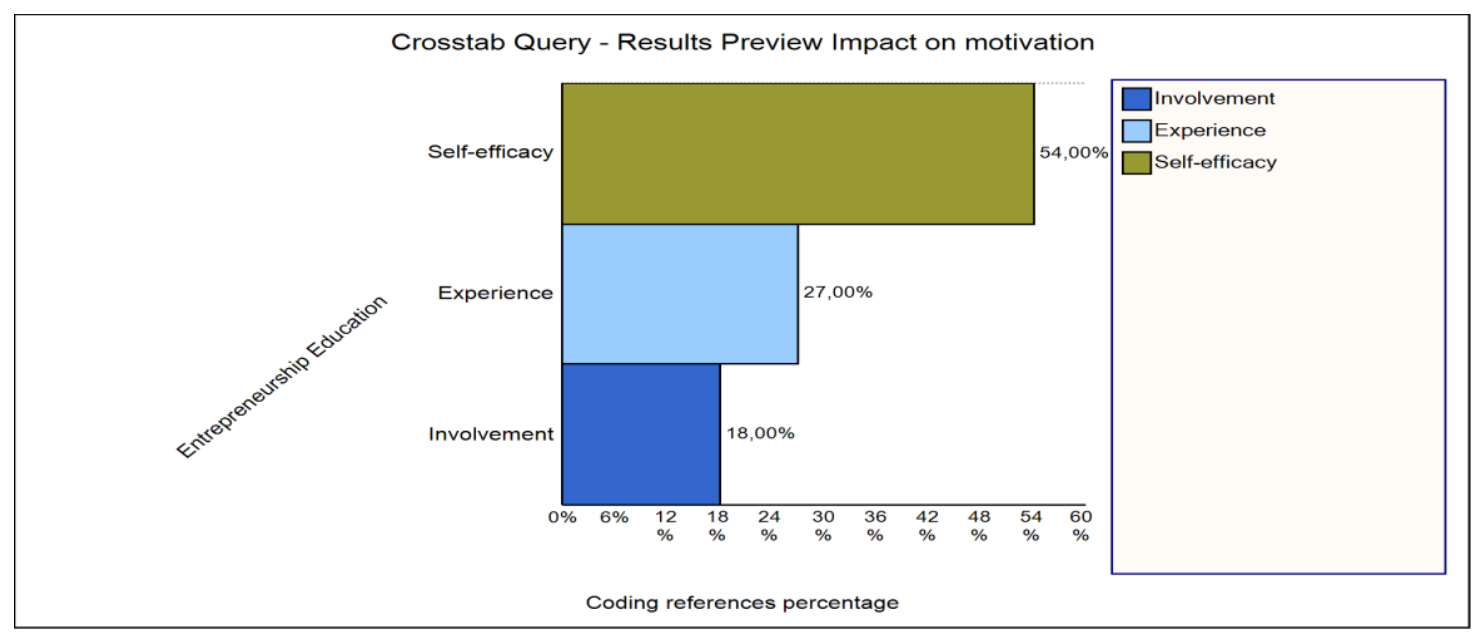

Figure 5. Application of a Gamification Strategy (Impact on Psychological Aspect based on Entrepreneurship Education)

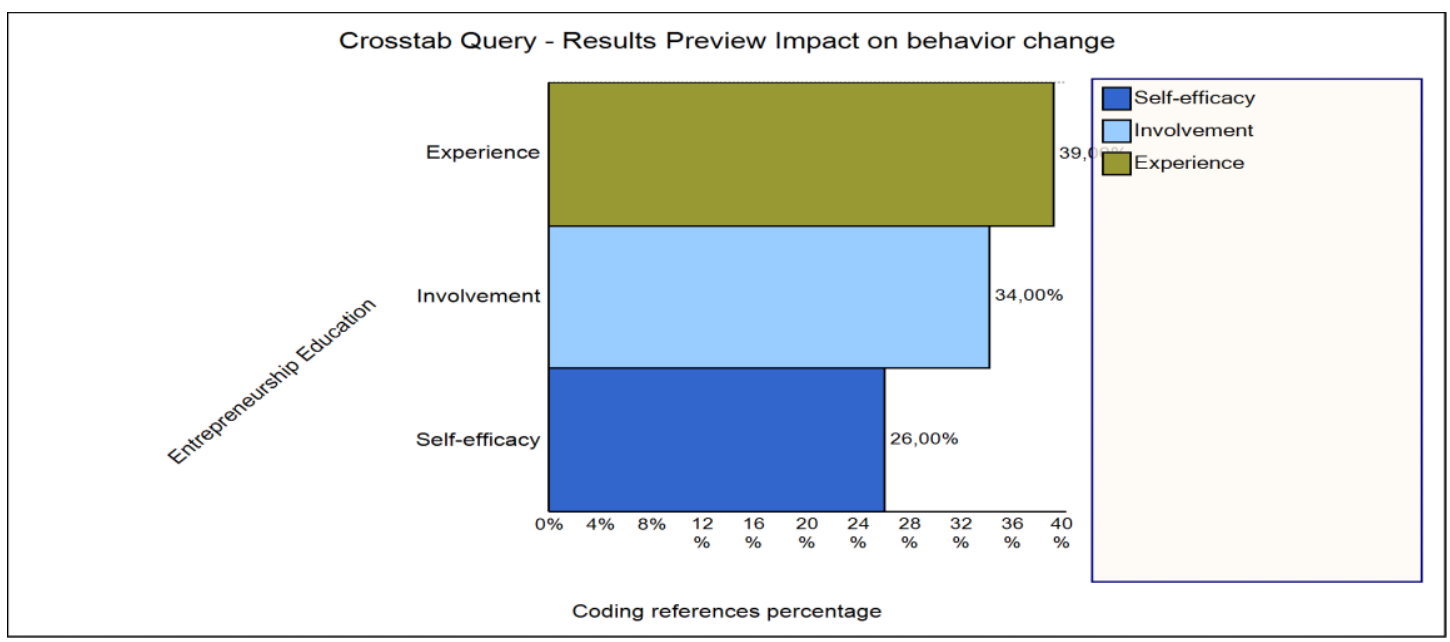

Figure 6. Application of a Gamification Strategy (Impact on Psychological Aspect based on Entrepreneurship Education) 


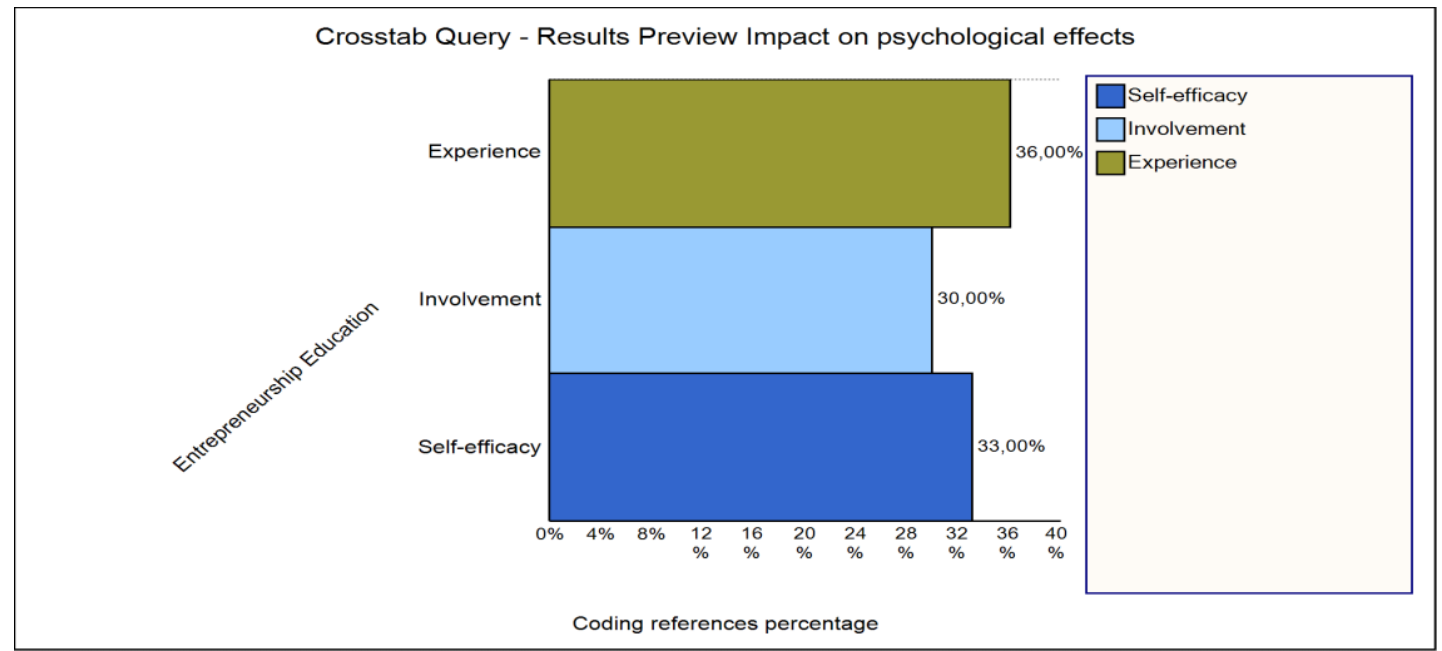

Figure 7. Application of a Gamification Strategy (Impact on Psychological Aspect based on Entrepreneurship Education)

The word similarity analysis (Figure 8) was carried out to obtain the similarity of relevant analysis related to cluster analysis intending to produce a diagram that classifies the mutually supportive relationship among the variables obtained. Entrepreneurial behavior and entrepreneurship education through applying a Gamification Strategy show that there is support from each other. Each element, such as self-efficacy, experience, involvement, attitudes, subjective norms, and behavioral control, have attachments that explain the success of the Gamification Strategy in its application.

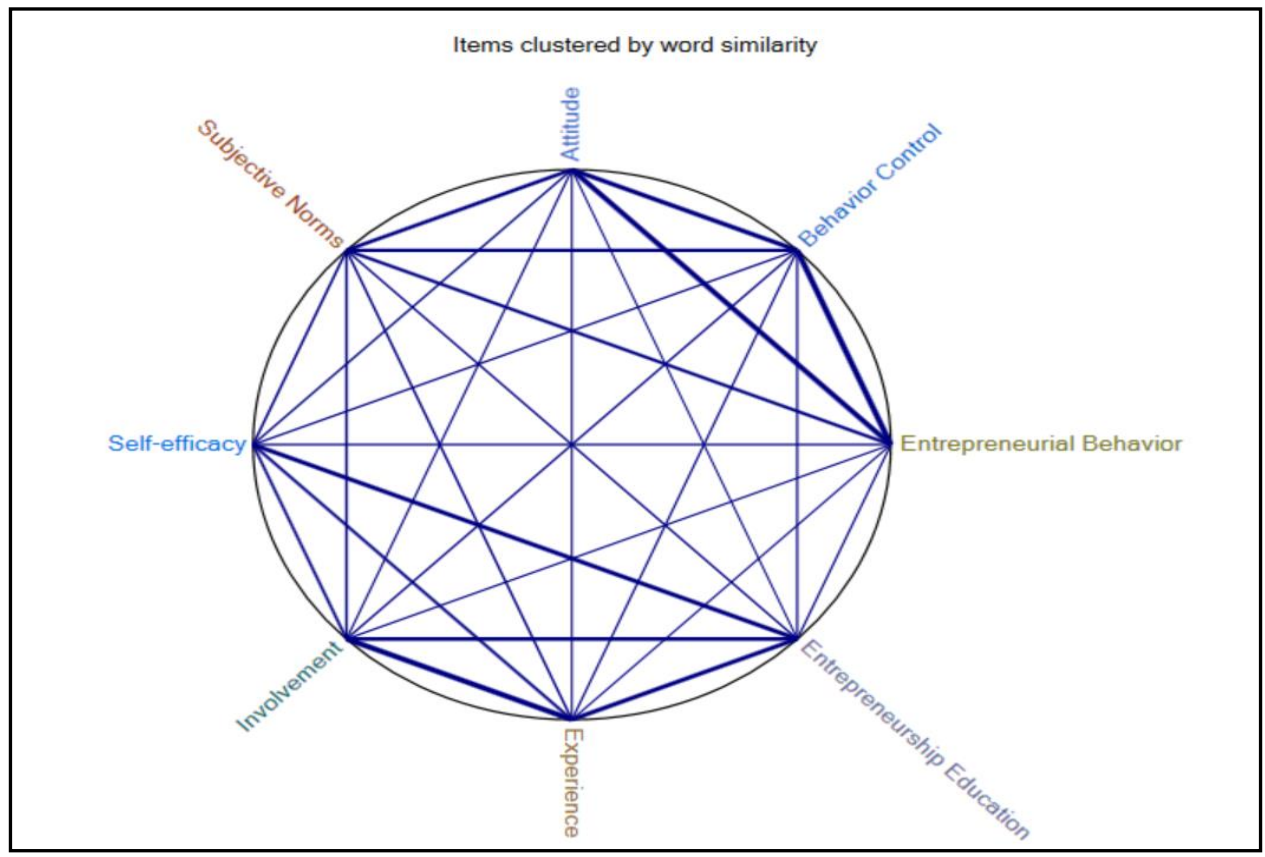

Figure 8. The Mutually Supportive Relationship in the Implementation of the Gamification Strategy 
This shows that the Gamification Strategy can be applied to business processes because it can answer problems that arise through entrepreneurial behavior and entrepreneurship education on the impact on motivation, behavior change, and the resulting psychological effects, to be a business recovery strategy in encountering unexpected moments, especially the current pandemic that caused decreased employee performance and changes in systems in business processes.

\section{Discussion}

According to Liñán and Fayolle (2015), in the development of studies conducted in the last ten years, 50 studies investigating entrepreneurial behavior were identified, but there were limited references in the application of gamification and entrepreneurship education. Indeed, the term gamification is relatively new and popular (Deterding, 2011). The definition of gamification is the use of game design elements in a non-game context. Nacke and Deterding (2017) stated that as a research area, gamification has recently grown tremendously and shows no indications of slowing down. The rapid development of this research topic is becoming a new multidisciplinary field.

Figures 1 to Figure 6 uncover that the presidium.ID as an MSME business applies a Gamification Strategy with entrepreneurial behavior and entrepreneurship education as a business recovery solution during the new normal era. Based on the results of a literature study, The tendency of gamification to influence motivation, behavior change, and psychological effects through self-determination theory (SDT), which focuses on the relationship between growth and psychological needs, including the need to feel competent, the need for autonomy, the need to feel connected to others, and the circumstances needed to motivate in enhancing the process of developing needs through behavior (Ryan \& Deci, 2000).

The development of entrepreneurial behavior locates support for a causal relationship to awareness through attitudes, subjective norms, and behavioral control in making decisions (Fretschner \& Weber, 2013; Vinichenko et al., 2016). An appropriate model for business development can be obtained in a pedagogical and learning setting by emphasizing the involvement of entrepreneurial education programs for skills development through experience and self-efficacy related to entrepreneurship (Konakli, 2015).

Figures 1 to Figure 7 delineate the application of the Gamification Strategy to each variable with a total percentage of $100 \%$. The entrepreneurial behavior variable and entrepreneurial education can provide a role and impact on the business process. Behavioral control is more dominant in entrepreneurial behavior, followed by elements of attitude and subjective norms sequentially. This is because the Gamification Strategy will be in direct contact with individuals who undergo business processes. 
Behavior control will be linked to a person's feelings about how easy or difficult it is to carry out various activities. This supports the findings of a study conducted by Aguiar-Castillo et al. (2020) explaining that gamification is employed to increase commitment and motivation to users. This fact, combined with the users' frequent usage of cellphones, has influenced the development of app-based gamification.

Because all activities are based on their position and beliefs, the element of attitude appears to be more steady in the use of the Gamification Strategy. This intends to generate greater motivation and commitment offered to alter business process behavior to make them more fascinating and enjoyable (Gears \& Braun, 2013). The same thing was also conveyed by Barber and Smutzer (2017) concerning efforts to be more productive.

Meanwhile, subjective norms become the element with the lowest percentage among others since it relates to one's perception of social pressure either to conduct behavior. For example, gamification is understood as using game techniques in a pleasant environment since it involves emotions in each individual who feels it (Deterding et al., 2011). Furthermore, due to cultural influences and perception from others' perspectives, subjective norms are a variable that tends to be weak (Entrialgo \& Iglesias, 2016).

In entrepreneurship education, experience is more dominant than self-efficacy and program involvement. This is because gamification is presented as an ideal tool that contributes to achieving education and training goals through resources (Lai et al., 2014). According to Marda (2020), when emotions and interest grow in students during the process of entrepreneurship education, deeper learning occurs via the process passed. For this reason, this study clarified whether gamification can be used as a strategy in promoting deep learning-oriented behavior. In particular, gamification analyzes the role characteristics of deep learning strategies.

Previous literature has shown that the educational and learning processes are influenced by cognitive factors such as psychological aspects and affective factors such as motivation (Fernández-Pérez et al., 2019). For instance, learning activities in entrepreneurship education are a source of pleasure and generate intrinsic motivation and little program involvement (McGonigal, 2011). This is why, in comparison to the other characteristics, involvement shows the lowest percentage.

In addition, the process of education and learning is influenced by behavior, such as psychological aspects (Parra-González et al., 2021). Furthermore, gamification is a game-based learning platform for entrepreneurship education with an effective learning method (Laski \& Siegler, 2014; Plass et al., 2013). In addition, self-efficacy appears to be more constant because it relates to a person's belief in accomplishing something. According to this study, gamification can help students learn and 
understand entrepreneurship education (Isabelle, 2020).

\section{Conclusion}

The application of gamification strategies plays a role in entrepreneurial behavior and education, which paves the way for intriguing research due to the paucity of a study examining business strategies in dealing with unexpected moments. The findings in this study indicate that gamification strategies have an impact on motivation, behavior change (a process of change experienced by humans based on what has happened), and psychological effects (closely related to the emotional regulation of individuals who tend to be prone to feeling tired and bored), and support each other in an element such as attitude, subjective norms, behavior control, self-efficacy, and involvement as a business recovery strategy in the new normal era. The limitation of this study deals with the scope of the MSME which has yet to be applied to other businesses. To compensate for this limitation, the concept of gamification can be used as a starting point for future study and applied to business in a variety of settings.

The results of this study contribute to the development of knowledge in entrepreneurship, business strategy, and particularly on improving individual performance. In practice, MSME businesses will face unexpected conditions such as the current pandemic. Therefore, a simple and relevant practical method that can answer the problem in a fun way is expected. To end, this research can be expanded to look into gamification strategies that are not only for individuals but in the realm of marketing, production, and financial systems.

\section{Authors' Declaration}

The authors made substantial contributions to the conception and design of the study. The authors took responsibility for data analysis, interpretation, and discussion of results. The authors read and approved the final manuscript.

\section{ORCID}

Arief Dwi Saputra (D) http://orcid.org/0000-0002-1462-6835

Alfina Rahmatia (D) https://orcid.org/0000-0002-8706-7659

Sri Handari Wahyuningsih (D) https://orcid.org/0000-0002-8840-3220

Andi Azhar (iD https://orcid.org/0000-0002-2542-6839

\section{References}

Aguiar-Castillo, L., Clavijo-Rodriguez, A., Hernández-López, L., De Saa-Pérez, P., \& Pérez-Jiménez, R. (2020). Gamification and deep learning approaches in higher education. Journal of Hospitality, Leisure, Sport and Tourism Education, 29, 1-14. https://doi.org/10.1016/j.jhlste.2020.100290

Antonaci, A., Dagnino, F. M., Ott, M., Bellotti, F., Berta, R., De Gloria, A., Lavagnino, 
E., Romero, M., Usart, M., \& Mayer, I. (2015). A gamified collaborative course in entrepreneurship: Focus on objectives and tools. Computers in Human Behavior, 51, 1276-1283. https://doi.org/10.1016/j.chb.2014.11.082

Fahriyah, A., \& Yoseph, R. (2020). Keunggulan Kompetitif Spesial sebagai Strategi Keberlanjutan UKM di Era New Normal. Prosiding Seminar STIAMI, 7(2), 104110.

Badan Pusat Statistik. (2020). Keadaan Ketenagakerjaan Indonesia Februari 2020. Berita Resmi Statistik. https://www.bps.go.id/publication/2020/06/19/

Barata, G., Gama, S., Jorge, J., \& Gonçalves, D. (2017). Studying student differentiation in gamified education: A long-term study. Computers in Human Behavior, 71, 550585. https://doi.org/10.1016/j.chb.2016.08.049

Barber C. S. and K. Smutzer. (2017). Leveling for Success: Gamification in IS Education. Proc. 23rd Am. Conf. Inf. Syst, pp 1-10.

Connie S. Barber. (2018). Book Review: 3D Game Lab: Rezzly Heroic Learning. Academy of Management Learning \& Education, 17(1), 112-115.

https://doi.org/10.5465/amle.2017.0419

Denny, P. (2013). The effect of virtual achievements on student engagement. Conference on Human Factors in Computing Systems - Proceedings, pp 763-772. https://doi.org/10.1145/2470654.2470763

Deterding, S. (2011). Situated motivational affordances of game elements: A conceptual model. CHI 2011 Workshop "Gamification," 3-6. http://gamificationresearch.org/chi2011/papers

Deterding, S. D Dixon, R Khaled, L. N. (2011). From game design elements to gamefulness: defining" gamification". Proceedings of the 15th International Academic MindTrek Conference: Envisioning Future Media Environments, MindTrek 2011, pp 9-15.

Dichev, C., \& Dicheva, D. (2017). Gamifying education: what is known, what is believed and what remains uncertain: a critical review. International Journal of Educational Technology in Higher Education, 14(9), 1-36. https://doi.org/10.1186/s41239-017-0042-5

Domínguez, A., Saenz-De-Navarrete, J., De-Marcos, L., Fernández-Sanz, L., Pagés, C., \& Martínez-Herráiz, J. J. (2013). Gamifying learning experiences: Practical implications and outcomes. Computers and Education, 63, 380-392. https://doi.org/10.1016/j.compedu.2012.12.020

Entrialgo, M., \& Iglesias, V. (2016). The moderating role of entrepreneurship education on the antecedents of entrepreneurial intention. International Entrepreneurship and Management Journal, 12(4), 1209-1232. https://doi.org/10.1007/s11365-016-0389-4 
Fathian, M., Sharifi, H., Nasirzadeh, E., Dyer, R., \& Elsayed, O. (2021). Towards a comprehensive methodology for applying enterprise gamification. Decision Science Letters, 10(3), 277-290. https://doi.org/10.5267/j.dsl.2021.3.002

Fernández-Pérez, V., Montes-Merino, A., Rodríguez-Ariza, L., \& Galicia, P. E. A. (2019). Emotional competencies and cognitive antecedents in shaping student's entrepreneurial intention: the moderating role of entrepreneurship education. International Entrepreneurship and Management Journal, 15(1), 281-305. https://doi.org/10.1007/s11365-017-0438-7

Fretschner, M., \& Weber, S. (2013). Measuring and understanding the effects of entrepreneurial awareness education. Journal of Small Business Management, 51(3), 410-428. https://doi.org/10.1111/jsbm.12019

Gears, D., \& Braun, K. (2013). Gamification in Business : Designing Motivating Solutions to Problem Situations. Proceding of Conference on Human Factors in Computing Systems, pp 5-12.

Gimenez-Fernandez, E., Abril, C., Breuer, H., \& Gudiksen, S. (2021). Gamification approaches for open innovation implementation: A conceptual framework. Creativity and Innovation Management, 30(3), 455-474. https://doi.org/10.1111/caim.12452

Hamari, J., Koivisto, J., \& Sarsa, H. (2014). Does gamification work? - A literature review of empirical studies on gamification. Proceedings of the Annual Hawaii International Conference on System Sciences, 3025-3034. https://doi.org/10.1109/HICSS.2014.377

Hendrawan, A., Yulianeu, A., Sucahyawati, H., \& Indriyani, I. (2018). Pengembangan Kompetensi UMKM Dengan Pembelajaran Organisasi. INOBIS: Jurnal Inovasi Bisnis Dan Manajemen Indonesia, 1(4), 489-496. https://doi.org/10.31842/jurnalinobis.v1i4.53

Hilal, S. Alabri. (2013). Using NVivo for data analysis in qualitative research. International interdisciplinary journal of education, 2(2), 181-186

Huotari, K. and Hamari, J. (2012). Defining gamification: a service marketing perspective. Proceedings of the IADIS International Conference Interfaces and Human Computer Interaction 2012, pp 227-231.

Huotari, K. and Hamari, J. (2017). A definition for gamification: anchoring gamification in the service marketing literature. Electronic Markets. 27(1), 21-31.

Isabelle, D. A. (2020). Gamification of Entrepreneurship Education. Decision Sciences Journal of Innovative Education, 18(2), 203-223. https://doi.org/10.1111/dsji.12203

McGonigal, J. (2011). Reality Is Broken: Why Games Make Us Better and How They Can Change the World. The penguin press.

Kalafato, Y. (2020). Gamification in Business : A Review of the Studies. Eurasian 
Studies in Business and Economics, 14(2), 53-73. https://doi.org/10.1007/978-3-03052294-0_4

Kevin Werbach, D. H. (2012). For the Win: How Game Thinking Can Revolutionize Your Business. Wharton School Press.

Konakli, T. (2015). Effects of self-efficacy on social entrepreneurship in education: A correlational research. Research in Education, 94(1), 30-43.

https://doi.org/10.7227/RIE.0019

Korn, O., \& Schmidt, A. (2015). Gamification of Business Processes: Re-designing Work in Production and Service Industry. Procedia Manufacturing, 3(AHFE), 3424-3431. https://doi.org/10.1016/j.promfg.2015.07.616

Kristensson, P., Wästlund, E., \& Söderlund, M. (2017). Influencing consumers to choose environment friendly offerings: Evidence from field experiments. Journal of Business Research, 76(1), 89-97. https://doi.org/10.1016/j.jbusres.2017.03.003

Kristina N. Bauer, C. G.-M. and D. A. G. (2020). Teaching with games and gamification: best practices and future research needs. Research Handbooks in Business and Management series. https://doi.org/10.4337/9781789901658.00041

Kuratko, D. F., \& Morris, M. H. (2018). Examining the Future Trajectory of Entrepreneurship. Journal of Small Business Management, 56(1), 11-23. https://doi.org/10.1111/jsbm.12364

Lai, C. H., Lin, Y. C., Jong, B. S., \& Hsia, Y. T. (2014). Adding social elements to gamebased learning. International Journal of Emerging Technologies in Learning, 9(3), 12 15. https://doi.org/10.3991/ijet.v9i3.3294

Larivière, B., Bowen, D., Andreassen, T. W., Kunz, W., Sirianni, N. J., Voss, C., Wünderlich, N. V., \& De Keyser, A. (2017). “Service Encounter 2.0”: An investigation into the roles of technology, employees and customers. Journal of Business Research, 79, 238-246. https://doi.org/10.1016/j.jbusres.2017.03.008

Laski, E. V., \& Siegler, R. S. (2014). Learning from number board games: You learn what you encode. Developmental Psychology, 50(3), 853-864. https://doi.org/10.1037/a0034321

Liñán, F., \& Fayolle, A. (2015). A systematic literature review on entrepreneurial intentions: citation, thematic analyses, and research agenda. International Entrepreneurship and Management Journal, 11(4), 907-933. https://doi.org/10.1007/s11365-015-0356-5

Mačiuliene, M., \& Skaržauskiene, A. (2016). Emergence of collective intelligence in online communities. Journal of Business Research, 69(5), 1718-1724. https://doi.org/10.1016/j.jbusres.2015.10.044

Marda, M. (2020). Enhancing Deeper Learning Using Empathy and Creativity in Roleplaying Serious Games (Doctoral dissertation, University of Westminster). 
Mwasalwiba, E. (2010). Entrepreneurship education: a review of its objectives, teaching methods, and impact indicators. Education Training,52(1), 20-47.

Nacke, L. E., \& Deterding, S. (2017). The maturing of gamification research. Computers in Human Behavior, 71, 450-454. https://doi.org/10.1016/j.chb.2016.11.062

Nurdiani, N. (2014). Teknik Sampling Snowball dalam Penelitian Lapangan. ComTech: Computer, Mathematics and Engineering Applications, 5(2), 1110-1118. https://doi.org/10.21512/comtech.v5i2.2427

Parra-González, M. E., López-Belmonte, J., Segura-Robles, A., \& Moreno-Guerrero, A.-J. (2021). Gamification and flipped learning and their influence on aspects related to the teaching-learning process. Heliyon, 7(2), e06254. https://doi.org/10.1016/j.heliyon.2021.e06254

Plass, J. L., O'Keefe, P. A., Homer, B. D., Case, J., Hayward, E. O., Stein, M., \& Perlin, K. (2013). The impact of individual, competitive, and collaborative mathematics game play on learning, performance, and motivation. Journal of Educational Psychology, 105(4), 1050-1066. https://doi.org/10.1037/a0032688

Poole, S., Kemp, E., Patterson, L., \& Williams, K. (2014). Get Your Head in the Game: Using Gamification to Connect with Generation Y in the Classroom. Journal for Excellence in Business Education, 3(2), 274-279. http://repository.usfca.edu/ml

Rauch, A., \& W Hulsink. (2015). Putting entrepreneurship education where the intention to act lies: An investigation into the impact of entrepreneurship education on entrepreneurial behavior. Academic of Management Learning $\mathcal{E}$ Education, 14(2), 187-204.

Robson, K., Plangger, K., Kietzmann, J. H., McCarthy, I., \& Pitt, L. (2016). Game on: Engaging customers and employees through gamification. Business Horizons, 59(1), 29-36. https://doi.org/10.1016/j.bushor.2015.08.002

Ryan, R. M., \& Deci, E. L. (2000). Intrinsic and Extrinsic Motivations: Classic Definitions and New Directions. Contemporary Educational Psychology, 25(1), 5467. https://doi.org/10.1006/ceps.1999.1020

Ryan, R. M., \& Deci, E. L. (2020). Intrinsic and extrinsic motivation from a selfdetermination theory perspective: Definitions, theory, practices, and future directions. Contemporary Educational Psychology, 61, 1-11. https://doi.org/10.1016/j.cedpsych.2020.101860

Ryan, R. M., Deci, E. L., \& Rochestu. (2014). Overview of Self-Determination Theory: An Organismic Dialectical Perspective. Handbok of Self-Determination, 1-33. http://www.elaborer.org

Sailer, M., \& Homner, L. (2020). The Gamification of Learning: a Meta-analysis. Educational Psychology Review, 32(1), 77-112. https://doi.org/10.1007/s10648-01909498-w 
Saputra, A. D. \& Rahmatia. A. (2021). Gamification Model as a Business Strategy for MSMEs in Indonesia. Journal of Accounting and Strategic Finance, 4(1), 91-107. http://jasf.upnjatim.ac.id/index.php/jasf/article/view/162

Seaborn, K., \& Fels, D. I. (2015). Gamification in theory and action: A survey. International Journal of Human Computer Studies, 74, 14-31. https://doi.org/10.1016/j.ijhcs.2014.09.006

Sholikhah, A. (2016). Statistik Deskriptif Dalam Penelitian Kualitatif. KOMUNIKA: Jurnal Dakwah Dan Komunikasi, 10(2), 342-362. https://doi.org/10.24090/komunika.v10i2.953

Storbacka, K., Brodie, R. J., Böhmann, T., Maglio, P. P., \& Nenonen, S. (2016). Actor engagement as a microfoundation for value co-creation. Journal of Business Research, 69(8), 3008-3017. https://doi.org/10.1016/j.jbusres.2016.02.034

Vesa, M., Hamari, J., Harviainen, J.T. and Warmelink, H. (2017). Computer games and organization studies. Organization Studies, 38(2), 273-284.

Vinichenko, M. V., Melnichuk, A. V., Kirillov, A. V., Makushkin, S. A., \& Melnichuk, Y. A. (2016). Modern views on the gamification of business. Journal of Internet Banking and Commerce, 21(S3), 12-19.

Wünderlich, N. V., Gustafsson, A., Hamari, J., Parvinen, P., \& Haff, A. (2020). The great game of business: Advancing knowledge on gamification in business contexts. Journal of Business Research, 106, 273-276. https://doi.org/10.1016/j.jbusres.2019.10.062 